\title{
The strategies of
}

\section{multinational companies in 1990s Argentina}

Daniel Chudnovsky

Director

dany@fund-cenit.org.ar

Andrés López

Researcher

anlopez@fund-cenit.org.ar

Centro de Investigaciones

para la Transformación

(CENIT), Buenos Aires
In the 1990s, Argentina received large amounts of foreign

direct investment and the participation of multinational

companies in the country's economy increased significantly.

As during the import substitution industrialization period, the basic goal of multinationals is still to exploit the domestic market. Two differences from that period can be observed, however: access to the Brazilian market allows for greater economies of scale and specialization, and increased competition in many tradable sectors is forcing subsidiaries to bring their operations closer to international best practice. These differences, though, are not reflected in the trading practices of subsidiaries. Although these have considerably higher import ratios than local firms, differences in the export ratios of the two types of companies are not statistically significant.

Multinationals' manufacturing exports go mainly to Mercosur, while their imports come principally from the developed countries. 


\section{I}

\section{Introduction}

One of the most striking features of the Argentine economy during the 1990s was the large influx of foreign direct investment (FDI) and the resultant increase in the presence of multinational companies in the country's market. Although Argentina had received large flows of investment of this kind at different stages in its history, particularly in the late 1950s and early 1960s, when the "hard" part of import substitution industrialization (ISI) began, there are a number of aspects of the recent FDI surge that make it unusual and particularly important.

Firstly, the largest FDI inflows seen in Argentina prior to the 1990s were between 1959 and 1963, when they averaged US\$ 464 million a year in today's money. In the 1990s, investment inflows of this kind averaged more than US\$ 6.76 billion a year. While FDI ran at about $0.3 \%$ of GDP between 1959 and 1963, it exceeded $2 \%$ almost every year in the 1990s. In fact, Argentina is one of the few developing countries to attract significant flows of foreign investment: between 1994 and 1999 it ranked fourth as an FDI recipient among developing countries, after China, Brazil and Mexico.

Consequently, the presence of multinationals ${ }^{1}$ in the Argentine economy is also much greater than it was in the past. To take the largest manufacturing firms, whereas in 1963 multinationals accounted for $46 \%$ of value-added and 36\% of employment, in 1997 the figures were $79 \%$ and $61 \%$, respectively. Again, the share of multinationals in the total sales of the 100 largest manufacturing firms rose from $43 \%$ in 1974 to $61 \%$ in 1998. Indeed, the advance of multinationals in

This article is based on the findings of a research project that was completed in March 2001 in the Mercosur Network, with financing from the International Development Research Centre (IDRC) of Canada and the Agencia Nacional de Promoción Cientifica $y$ Tecnológica in Argentina. The authors wish to thank Laura Abramovsky for her valuable assistance in collecting and processing the statistical material used in this paper.

${ }^{1}$ The term "multinational" is used here to refer to all companies that have more than $10 \%$ of their share capital held by non-residents (following the IMF criterion that uses the $10 \%$ threshold to distinguish between portfolio investment and direct investment). In fact, most of the multinationals operating in Argentina are more than $50 \%$ foreign-owned. the 1990s puts them among the clear "winners" in the restructuring that has taken place in the Argentine economy since the adoption of the Convertibility Plan and the implementation of a far-reaching programme of pro-market structural reform, which has drastically changed the ground rules of the country's economy.

Secondly, and essentially as a result of the reform programme just referred to, the domestic context has altered greatly. Whereas during the import substitution industrialization phase the Argentine economy was virtually closed to imports that competed with local output, from the late 1980s onward significant progress was made towards freer trade, including integration with Brazil, Paraguay and Uruguay in Mercosur.

Thirdly, during the substitution phase FDI went first and foremost into the manufacturing sector, while in the 1990s services played a much greater role as the weight of the industrial sector in the economy diminished. Again, whereas FDI during the import substitution period went mainly into greenfield investments, in the 1990s the bulk of investment went into purchases of existing companies (including privatized public-sector companies).

Lastly, the international context too is different from what it was in the past. Although FDI flows around the world expanded substantially in the 1950s and 1960s, in the 1990s there was a greater impetus towards globalization, one of whose most distinctive features has been the rapid growth of FDI. Measured at current values, world FDI flows increased from an annual average of US\$ 115 billion in 1984-1989 to an average of some US\$ 500 billion in 1994-1999. Globalization has also led to qualitative changes in the logic of FDI deployment, such as the growing importance of mergers and acquisitions and the reshaping of intracompany relationships to achieve greater linkage between the different subsidiaries and their head offices, not only commercially but also as regards technology and production methods.

Given this context, it is clearly important to analyse the determinants, types and effects of the great influx of FDI that went into Argentina in the 1990s. Chudnovsky and López (2001) present the results of a research project that looked into these issues. In the present article, which partly draws on that work, the

THE STRATEgIES OF MULTINATIONAL COMPANIES IN 1990S ARGENTINA • DANIEL CHUDNOVSKY AND ANDRÉS LÓPEZ 
analytical objectives are more narrowly defined, and the essential aim is to consider the extent to which the strategies and behaviour of the subsidiaries of multinationals in the new circumstances of the 1990s differed from what had been seen in the substitution industrialization period.

During ISI, the basic motivation of multinational companies investing in Argentina was the desire to exploit the protected domestic market ("jumping the tariff"). ${ }^{2}$ Their subsidiaries had little production complementation and/or linkage with their peers elsewhere in the company, and the little they exported went mainly to Latin American markets. They imported quite substantially, however, mainly goods that could not be produced locally because of the scales or the degree of technological complexity involved. These imports came mainly from the home countries of their parent companies, and from other developed countries. These subsidiaries performed better in terms of productivity, technology assets, etc., than locally owned firms, but because they were operating in an environment that offered relatively few incentives for technical progress and efficiency-seeking, the technologies and productivity levels they worked with tended to fall further and further behind international best practice. In certain respects, in short, the subsidiaries of multinationals showed a tendency to accentuate the main problems of the substitution model. ${ }^{3}$

By contrast, in the new circumstances of the 1990s the expectation, particularly among orthodox economists, was that FDI would be not only a source of balance-of-payments financing, but also a key element in the restructuring of the domestic economy to raise

\footnotetext{
${ }^{2}$ Even in the days when the agricultural export model prevailed, of course, there were multinationals in Argentina engaged in exploiting natural resources, chiefly agricultural, with a view to export. Although this type of operation not only continued but expanded during the import substitution stage, the purpose of most of the FDI that arrived then was to exploit the domestic market.

${ }^{3}$ See Sourrouille, Gatto and Kosacoff (1984), Sourrouille, Lucangeli and Kosacoff (1985) and Kosacoff and Aspiazu (1989).
}

its efficiency and level of integration with the world economy. This type of reasoning is embodied in the World Development Report 1991 (World Bank, 1991), where many of the ideas and recommendations of the so-called Washington Consensus were developed. According to the World Bank, FDI leads to losses of welfare when it is carried out in countries that follow "distorting" policies, such as high levels of import protection (as in the case of ISI). In open economies with investor-friendly laws, by contrast, multinationals abandon their old focus on the domestic market, increase their exports by exploiting their links with international markets, and at the same time increase their productivity rapidly (World Bank, 1991). The argument that multinationals stimulate export growth in recipient economies is also found in the World Development Report 1999/2000 (World Bank, 2000). To sum up, the expectation was that multinationals would not aggravate economic weaknesses as they had during ISI, but would help to strengthen the potentialities of the economic regime adopted in the 1990s.

In earlier studies (Chudnovsky, Porta and others, 1996 and Chudnovsky and López, 1996) we found that multinationals played a much more limited role in export growth than this orthodox view maintained, and that their strategies continued to focus mainly on the domestic market, although they were indeed more efficient than companies operating under the substitution industrialization model. Now that more time has passed since the reforms began, and new empirical evidence has been analysed, the findings of the present study bear out the results of our previous research.

Given this situation, this article sets out to answer the following questions. To what extent do the strategies and objectives of multinational companies differ, in the context of an economy that is more open now than in the past, from those that prevailed during the substitution industrialization phase? If there are differences, how did they manifest themselves in the external trade patterns of these companies' subsidiaries in the 1990s? And in particular, have multinationals altered their trading strategies along the lines predicted by the orthodox theory? 


\section{II}

\section{The strategies of multinational companies}

To analyse the strategies and operating methods adopted by multinationals in Argentina in the 1990s, we shall rely mainly on the conceptual framework provided by the so-called "eclectic paradigm" of foreign direct investment (Dunning, 1988 and 1996). This classifies FDI by purpose into four main types:

i) Resource-seeking investment. This seeks to exploit natural resources or unskilled labour, whose availability is obviously the main locational advantage offered by the recipient country. Investments of this type are generally export-oriented and tend to operate as enclaves within the host country.

ii) Market-seeking investment. This aims to exploit the domestic market of the recipient country (and sometimes the markets of other countries nearby). The size and growth rate of the market, the existence of physical barriers and/or high transport costs and the industrialization strategy of the recipient country, including decisions about the degree of protection for local output, are decisive factors for this type of FDI, which was the dominant one in Latin America during the ISI phase.

iii) Efficiency-seeking investment. This type of investment tends to follow the previous type as competition conditions are modified by economic development, trade liberalization or the emergence of local competitors. Its aim is to rationalize production in order to exploit economies of specialization and scope. Regional integration, falling transport costs and advances in telecommunications favour this type of investment, which generally goes into trade and production activities designed to complement the operations of the multinational company's subsidiaries.

iv) Strategic asset-seeking. It seems that FDI of the first two types is now yielding primacy to investment of this fourth type. "The main purpose [of this type of strategy] is to acquire resources and capabilities that an investing firm believes will sustain or advance its core competencies in regional or global markets. These assets may range from innovatory capability and organisational structures to accessing foreign distribution channels and a better appreciation of the needs of consumers in unfamiliar markets" (Dunning, 1996, p. 36).
In turn, shifts in multinationals' strategies and objectives have given rise to changes in the way their subsidiaries fit into the company's operations. Thus, market-seeking strategies led on to the creation of standalone subsidiaries. These reproduce the organization of the parent company on a smaller scale, generally with the exception of research and development activities, which tend to be concentrated in the home country (UNCTAD, 1994).

As cost competition begins to prevail in certain industries, national consumption patterns converge and transport costs fall, there is a shift in some cases to "simple integration" strategies, in which the subsidiary specializes in certain stages of the value chain (usually labour-intensive ones) as part of the outsourcing arrangements established by the company. This type of strategy obviously tends to increase the volume of external trade generated by FDI, as subsidiaries not only export much of their output, but generally operate with only a low level of national integration. Lastly, UNCTAD (1994) speaks of what it terms a "complex integration" strategy, in which multinationals turn their subsidiaries into an integral part of regionally or globally integrated distribution and production networks. Thus, the value chain is broken down into functions (assembly, finance, research and development, marketing, etc.) that are situated wherever they can be carried out most efficiently for the company as a whole. In this way, production and management functions of strategic importance to the company may be based in subsidiaries.

To analyse the strategies of multinationals in the case of Argentina, a range of indicators bearing on the external trade of their subsidiaries was studied, and a typology of strategies by sector was generated on the basis of this examination. In this way it was possible to establish four groupings that differ essentially depending on the types of sector involved in each case and their greater or lesser propensity to export, but that also display specific characteristics in their approach to Mercosur, among other factors (table 1). ${ }^{4}$

\footnotetext{
${ }^{4}$ The sample from which the data included in this table were calculated were the 1,000 largest Argentine firms by sales in 1992 and 1997. The sales of companies in this sample represented 35\% and $44 \%$ of GDP, respectively.
} 
TABLE 1

Subsidiaries of multinational companies in Argentina: a sectoral typology of their strategies, 1992 and 1997

(Percentages and millions of dollars)

\begin{tabular}{|c|c|c|c|c|c|c|c|c|c|c|}
\hline & \multicolumn{7}{|c|}{1997} & \multicolumn{3}{|c|}{1992} \\
\hline & $\mathrm{X}$ ratio ${ }^{\mathrm{a}}$ & M ratio ${ }^{\mathrm{a}}$ & $\begin{array}{c}\mathrm{X} \text { to } \\
\text { Mercosur }^{\mathrm{b}}\end{array}$ & $\begin{array}{c}\text { M from } \\
\text { Mercosur }^{b}\end{array}$ & $\begin{array}{c}\text { X ratio } \\
\text { without } \\
\text { Mercosur }\end{array}$ & $\begin{array}{c}\text { Trade } \\
\text { balance } \\
\text { (mill. dol.) }\end{array}$ & $\begin{array}{c}\% \\
\text { sales }^{\mathrm{d}}\end{array}$ & $\mathrm{X}$ ratio ${ }^{\mathrm{a}}$ & $\begin{array}{c}\mathrm{X} \text { to } \\
\text { Mercosur }\end{array}$ & $\begin{array}{c}\text { X ratio } \\
\text { without } \\
\text { Mercosur }^{\mathrm{c}}\end{array}$ \\
\hline Total & 15.0 & 18.8 & 50.6 & 19.5 & 9.3 & 802 & 100.0 & 17.6 & 30.3 & 14.8 \\
\hline Resource-seeking strategy & 71.8 & 2.1 & 22.5 & 8.0 & 59.2 & 5,746 & 12.2 & 71.3 & 8.6 & 64.9 \\
\hline Fisheries & 87.8 & 2.9 & 2.1 & 0.0 & 86.1 & 137 & 0.3 & 64.7 & 0.1 & 64.6 \\
\hline Oils and grains & 84.5 & 1.0 & 16.4 & 12.7 & 69.6 & 4,570 & 8.2 & 88.4 & 17.2 & 72.9 \\
\hline Commodities marketing ${ }^{\mathrm{e}}$ & 81.6 & 2.9 & 7.2 & 2.8 & 75.2 & 180 & 0.5 & 81.2 & 0.6 & 80.8 \\
\hline Leather and manufactures thereof & 76.2 & 8.3 & 5.3 & 22.8 & 73.2 & 194 & 0.4 & 64.5 & 33.1 & 42.7 \\
\hline Petroleum & 45.3 & 1.6 & 54.0 & 1.2 & 26.9 & 522 & 2.3 & 15.4 & 0.0 & 15.4 \\
\hline Meat products & 44.1 & 1.8 & 21.7 & 1.6 & 30.9 & 143 & 0.5 & 53.9 & 0.4 & 53.6 \\
\hline \multicolumn{11}{|l|}{ Domestic market-seeking } \\
\hline strategy & 0.8 & 16.2 & 12.6 & 11.0 & 0.7 & $-2,227$ & 38.1 & 1.7 & 22.0 & 1.6 \\
\hline \multicolumn{11}{|l|}{ Import trade with technical } \\
\hline assistance component $^{\mathrm{f}}$ & 4.7 & 41.2 & 12.5 & 6.5 & 4.4 & -471 & 1.3 & 4.0 & 19.7 & 3.8 \\
\hline Electricity, gas and water & 0.8 & 5.1 & 12.0 & 10.5 & 0.7 & -134 & 9.1 & 0.0 & 0.0 & 0.0 \\
\hline Construction and engineering & 0.1 & 2.9 & 8.1 & 6.5 & 0.1 & -9 & 0.3 & 0.7 & 14.9 & 0.6 \\
\hline Telephony services & 0.1 & 24.2 & n.c. & 2.5 & 0.1 & -774 & 9.7 & 0.0 & 0.0 & 0.0 \\
\hline Wholesale and retail trade & 0.1 & 32.1 & n.c. & 20.8 & 0.1 & -675 & 11.0 & 1.0 & 0.0 & 1.0 \\
\hline Transport and storage & 0.0 & 3.0 & n.c. & 2.0 & 0.0 & -71 & 2.8 & 0.0 & 0.0 & 0.0 \\
\hline Television and multimedia & 0.0 & 7.4 & n.c. & 0.1 & 0.0 & -67 & 1.1 & - & - & - \\
\hline Other services & 0.0 & 1.6 & n.c. & 11.0 & 0.0 & -26 & 2.8 & 0.2 & 36.0 & 0.1 \\
\hline \multicolumn{11}{|l|}{ Moderate-export market-seeking } \\
\hline strategy & 15.9 & 29.0 & 59.8 & 27.7 & 6.1 & $-1,682$ & 25.8 & 10.5 & 40.6 & 7.4 \\
\hline Cars and car parts & 24.8 & 31.7 & 69.3 & 40.7 & 4.3 & -334 & 12.8 & 11.1 & 37.5 & 8.9 \\
\hline Textiles and wearing apparel & 17.5 & 32.1 & 91.3 & 56.3 & 1.5 & -6 & 0.2 & 14.4 & 52.2 & 12.4 \\
\hline Cellulose and paper & 15.1 & 17.2 & 60.6 & 24.9 & 9.5 & -14 & 1.5 & 4.3 & 42.4 & 3.6 \\
\hline Chemical and petrochemical industry & 14.6 & 27.2 & 53.9 & 22.5 & 7.9 & -757 & 8.2 & 11.8 & 37.6 & 8.1 \\
\hline Plastic and rubber products industry & 11.2 & 31.1 & 63.2 & 30.6 & 3.1 & -170 & 1.0 & 2.3 & 50.6 & 1.1 \\
\hline Engineering and machinery & 10.3 & 30.1 & 57.0 & 20.2 & 4.8 & -194 & 1.1 & 12.5 & 48.6 & 7.7 \\
\hline Home electrical/consumer electronics & 10.0 & 38.3 & 80.2 & 17.8 & 1.8 & -207 & 1.0 & 0.1 & 46.9 & 0.1 \\
\hline Low-export market-seeking strategy & 6.7 & 16.6 & 62.0 & 19.9 & 2.3 & $-1,052$ & 23.4 & 5.3 & 40.0 & 2.9 \\
\hline Glass and non-metallic minerals & 9.1 & 10.2 & 51.2 & 21.0 & 3.8 & -11 & 1.0 & 6.2 & 25.1 & 4.4 \\
\hline \multicolumn{11}{|l|}{ Electrical and electronic } \\
\hline equipment and machinery & 7.5 & 34.6 & 53.2 & 16.8 & 2.8 & -383 & 2.2 & 7.3 & 39.2 & 4.5 \\
\hline Food, beverages and tobacco & 7.3 & 9.5 & 61.0 & 27.3 & 2.2 & -18 & 10.1 & 5.9 & 38.6 & 2.3 \\
\hline Pharmaceutical industry & 6.0 & 3.5 & 68.3 & 6.8 & 1.7 & -518 & 2.2 & 4.0 & 53.5 & 2.6 \\
\hline Fuels and petroleum derivatives & 4.8 & 7.4 & 72.0 & 16.8 & 2.0 & -87 & 7.5 & 3.1 & 30.6 & 2.2 \\
\hline Publishing/graphics industry & 2.9 & 19.7 & 97.3 & 17.0 & 0.1 & -35 & 0.4 & 0.4 & 0.0 & 0.4 \\
\hline
\end{tabular}

Source: Prepared by the authors on the basis of external trade statistics.

a All ratios calculated as an average of individual company ratios. $\mathrm{X}=$ exports, $\mathrm{M}=$ imports.

b Exports (imports) to (from) Mercosur as a percentage of total exports (imports).

c Exports to non-Mercosur destinations as a percentage of total sales.

d Sales of each sector as a percentage of total sales by multinationals.

e Includes wool, fruit, etc.

f This category covers companies that distribute imported goods (essentially goods connected with information technology and telecommunications and inputs for the agricultural sector) and that, in addition to marketing, provide technical assistance services to purchasers. This category was introduced to distinguish operations of this type from others where the activity is exclusively commercial (retail trade, household goods stores, etc.). 
One group with very well defined characteristics is the group of sectors in which resource-seeking FDI predominates, attracted by Argentina's natural comparative advantages. In 1997, companies in this grouping (which is much the smallest one) accounted for $12 \%$ of the total turnover of the multinationals ranking among the country's 1,000 largest firms. Of the four groups, this resource-seeking one is the only one to show a trade surplus. It includes companies that are clearly oriented towards the external market (the average export ratio is in excess of $70 \%$, and they generally export over $50 \%$ of sales), and that operate with very low import levels. Mercosur provides only a very small proportion of these companies' few imports, and although it is a fairly important market for exports (particularly of petroleum and, to a lesser extent, of oils and grains and meat products), in 1997 the nonMercosur export ratio of this group of sectors (i.e., exports outside the area as a percentage of each company's total sales) averaged about $60 \%$. It may be imagined that the subsidiaries of multinationals in this category are only loosely integrated into their parent companies and that inter-subsidiary complementation and/or specialization strategies are uncommon. Each subsidiary's operating links with the rest of the company consist essentially in exports of commodities from Argentina, which implies that the dominant operating methodologies in this group of companies are of the stand-alone type.

The other extreme as regards market orientation is found in sectors whose strategies are purely marketseeking: trade, services, transport, construction. This grouping is the largest one, accounting for $38 \%$ of all sales by the multinationals ranking among Argentina's largest companies. The multinationals operating in these sectors hardly export at all, and only a few industries have high import coefficients (imports of final goods in the case of trade, and essentially of equipment and inputs in the case of telephony services). For them, Mercosur is not by and large a significant source of imports. The companies in this grouping run a large trade deficit, since although their average import ratio is not particularly high by the standards of multinationals in Argentina generally, their exports, as mentioned above, are virtually nil. Strong intersubsidiary integration and/or specialization strategies seem to be equally lacking here, at least in goods trade, although consideration should be given to the possibility that such strategies might be found in other areas (such as television, multimedia or telephony services). In any event, the evidence available indicates that in this grouping, as in the previous one, it is stand-alone strategies that predominate.

The other two groupings (market-seeking sectors with low exports and market-seeking sectors with moderate exports) include industrial sectors whose main focus is on the domestic market. In 1997, each of these two groups accounted for about $25 \%$ of all sales by the multinationals ranking among the country's largest companies. The distinction between the two was established on the basis of the average export ratio of the Argentine economy in 1997, which was a little over $9 \%$. Thus, sectors whose ratios were similar to or lower than the national average were classified as low-export sectors, while those activities whose export ratios were higher than this average were classed as moderate exporters, the year taken being 1997 in all cases.

Many of the low-export sectors are producers of consumer goods (pharmaceuticals, food, drinks and tobacco), and product differentiation, be it by branding, technical characteristics, advertising or other aspects, is crucial to the way they compete. The electrical and electronic equipment and machinery sector also produces some consumer goods for markets with similar forms of dominant competition. This type of competition is also important in fuels and petroleum derivatives. Multinationals operating in these sectors have an average export ratio of $6.7 \%$, which is well below their average import ratio of $16.6 \%$; unsurprisingly, then, the operations of this group generate a large trade deficit. Table 1 shows that in the electrical and electronic equipment and machinery sector and the pharmaceutical sector, the import ratio is about five times the export ratio on average, and in the publishing and graphics industries it is over six times. Mercosur takes $62 \%$ on average of what companies in this group export. Thus, we find that exports beyond Mercosur average a bare $2.3 \%$ of lowexport market-seeking multinationals' sales. The percentage of imports sourced from Mercosur is much lower at $20 \%$.

Lastly, in the group of sectors that export moderately (but are still focused on the domestic market) there is a discernible tendency to follow more open external trade strategies and to seek strong integration with Mercosur, particularly where exports are concerned. The average export ratio of these companies $(16 \%)$ is lower than their import ratio (29\%). As a result, they run a large trade deficit, particularly in the chemicals/petrochemicals sector.

Even the sectors in this more export-oriented group basically concentrate on Mercosur, and non-Mercosur

THE STRATEGIES OF MULTINATIONAL COMPANIES IN 1990S ARGENTINA • DANIEL CHUDNOVSKY AND ANDRÉS LÓPEZ 
exports average just $6.1 \%$ of sales. Only in the chemicals/petrochemicals and cellulose/paper sectors does the non-Mercosur export ratio exceed this, while sectors such as household electrical appliances/ consumer electronics and textiles export almost exclusively to Mercosur. In other words, manufacturing multinationals are now following market-seeking strategies in the broader ambit of Mercosur, but export very little to markets beyond it $(4.4 \%$ is the average for all subsidiaries in this group).

What happens when we compare the indicators for 1992 with those for 1997? Two groups show little change: the resource-seeking group of sectors (although the proportion of exports going to Mercosur increased) and the purely market-seeking group of sectors. In both low-export and moderate-export manufacturing sectors, the average export coefficient rose (most markedly in those sectors that exported moderately in 1997) and the proportion of external sales going to Mercosur increased sharply. Thus, in both groupings the share of non-Mercosur markets in total sales tended to fall between 1992 and 1997. In other words, whereas consideration of changes in export ratios might give the impression that the strategies of multinationals became less market-seeking between those two years, when the Mercosur dimension is brought in we find that the opposite was what tended to happen, since nonMercosur exports as a proportion of total sales were lower in 1997 than in 1992. The only exceptions to this general rule were the chemicals/petrochemicals sector and, very marginally, the household electrical/consumer electronics sector and the plastic and rubber products industry. ${ }^{5}$

The evidence that market-seeking strategies are strongly dominant in the subsidiaries of multinational companies is consistent with the findings of previous studies into the subject (Chudnovsky, Porta and others, 1996; Kosacoff and Porta, 1997 and Porta, 1999), which also agree that the size and growth rate of the domestic market were the main attractions for FDI going into Argentina in the $1990 \mathrm{~s}$. As was noted in the introduction, the same was true of the strategies and determinants of FDI in the ISI stage. There are two significant differences, however, from the dynamic that prevailed in that period.

\footnotetext{
${ }^{5}$ To ascertain how far the changes in the indicators referred to were due to shifts in the strategies of existing multinationals or to the entrance of new "players", a homogeneous panel of companies was analysed (i.e., companies operating both in 1992 and in 1997). In general, the results were consistent with the exercise just described, and bore out its conclusions.
}

Firstly, as has just been noted, the market that multinationals are trying to succeed in is not just the Argentine one, but in many cases the wider regional market, Mercosur. This offers scope, in principle, for greater economies of scale and specialization and hence greater efficiency than in the ISI phase. According to the standard literature, it is essentially through efficiency-seeking strategies (of which more later) that these gains can be realized.

Secondly, at a time of freer trade market-seeking strategies need to include rationalization and modernization measures designed to improve the productivity and quality of local processes and products. Earlier studies (Chudnovsky, Porta and others, 1996 and Kosacoff and Porta, 1997) show that multinationals have indeed taken action of this type, although efficiency gains have not always been passed on "downstream" to customers or consumers. Whether this has happened or not has generally depended on whether there is real competition in the markets concerned (something that is not always guaranteed by trade liberalization alone) and/or whether there are effective systems of regulation to constrain the ability of companies in particular sectors to abuse their dominant position (this is a crucial issue for privatization; in the case of Argentina, the scope of regulatory requirements and the degree of enforcement have varied very greatly among the different sectors involved).

The need for the subsidiaries of multinationals to implement efficiency measures is part of the restructuring process seen in the Argentine productive sector in the 1990s. Multinationals, it should be remembered, have been in a privileged position because of their greater technological and financial capabilities, their ability to use the know-how and experience accrued in other subsidiaries of the company to rationalize and modernize local structures, and the ease with which they can take advantage of freer trade through intracompany trade flows. Thus, multinationals have mainly led what Kosacoff (ed., 1998) has defined as "offensive restructurings", making what have often been large investments and implementing profound organizational changes, as a result of which they have secured major productivity improvements that have brought them closer to international best practice.

These efficiency measures, though, do not always form part of efficiency-seeking strategies as defined by Dunning. When forced to reduce costs (by trade liberalization), the subsidiaries of multinationals may implement rationalization or efficiency measures that 
do not necessarily involve closer links with other subsidiaries of the same company.

Efficiency-seeking strategies are taking on greater importance as well, however, particularly within Mercosur. Many multinationals operating in tradable sectors have tended or are tending to adopt a strategy of specialization in certain products or lines of production, and of complementation with other subsidiaries of the same company (particularly those operating in Brazil), shaping a production function that is open in respect of processes (inputs) and products.

Kosacoff and Porta (1997) detected the presence of strategies with efficiency-seeking components in certain sectors, namely food and beverages (branded products), cleaning and toiletry articles, household electrical appliances, packaging and cars and car parts. These strategies, logically enough, were implemented more quickly by "newcomers", whose planning included specialization and complementation among subsidiaries from the outset, than among established firms. With the latter, the specialization process began with the importation, generally from another subsidiary of the multinational concerned, of finished products to extend the variety of supply or test the market, or of inputs to bring down the cost of local production, while progress towards specialization systems based on relocation of activities among subsidiaries was at an early stage, and varied among the different companies and sectors studied. Thus, it was no surprise to find that in many cases trade flows of this type were still heavily dependent on demand cycles in the local markets concerned.

Examination of current trade flows by company and by sector yields new evidence that use is being made of specialization strategies designed to improve efficiency. This is clear from the fact that a number of companies' exports are heavily concentrated in one or just a few product lines (and are heavily focused on Mercosur, as was mentioned earlier), while imports of both inputs and finished goods are very diverse.

It is only in the automotive industry, though, that solid, efficiency-oriented integration strategies, mainly within Mercosur, seem to be becoming the rule. This is chiefly the result of two factors: i) the importance that Mercosur has taken on in the globalized competition among the major car manufacturers, and ii) the existence of different regimes for car production activities in Argentina and Brazil, which have encouraged specialization and integration between the two countries' industries.

In other sectors, specialization strategies still seem to depend on macroeconomic fluctuations, as has been seen since the devaluation of the real in January 1999 and the long recession that began in Argentina in late 1998. These events have led a number of multinationals to shut down production lines or even whole plants in Argentina, with production being shifted in many cases to Brazil.

As efficiency-seeking strategies begin to be implemented, so at the same time a gradual shift is taking place from the type of stand-alone subsidiaries characteristic of ISI to working methods based on forms of simple integration. The evidence available indicates that, by and large, greater integration is confined almost entirely to part of the product range on offer and does not include transfer of any of the multinational's strategic functions. In particular, Argentine subsidiaries do not carry out research and development or process and product design in-house, and they are given only partial responsibility for marketing and market development activities (Kosacoff and Porta, 1997). These authors maintain that the simple integration taking place in industries such as branded foods, cleaning and toiletry articles, household electrical appliances and car parts is weak, and only in the automotive sector, where efficiency-seeking strategies are more highly developed, do strong forms of integration appear to be emerging.

Lastly, asset-seeking strategies focus on the acquisition of existing companies. It is found that, generally speaking, the market position of the company being taken over has mattered far more as an investment determinant than its level of equipment. Multinationals acquiring public service enterprises did not generally set a high value either on the physical and technological assets nor on the human capital that these had before privatization (Chudnovsky, Porta and others, 1996). In any event, the strategic character of the assets sought by some multinationals to invest in depends essentially on these companies' operations in Argentina or, at most, in Mercosur, and they are rarely strategic for the global performance of the company concerned. 


\section{III}

\section{The external trade of multinational companies}

In the previous section we ascertained that the subsidiaries of multinationals tend to export little -and less than they import- and that their external trade, particularly exports, is largely bound up with Mercosur. We now need to look a little more closely at the trading patterns of companies of this kind, and contrast them with those of locally owned companies operating in Argentina.

To what extent does the trade performance of multinationals resemble or differ from that of local ones? The information available reveals a striking contrast in the trade balances of the two types of firms. In 1997, when the Argentine balance of trade was in deficit by US\$ 2.126 billion (using FOB values for both imports and exports and taking the 1,000 companies with the largest sales), we find that multinationals had a surplus of US\$ 803 million, while local firms had a surplus of US\$ 5.042 billion (table 2). Excluding companies that exported commodities or products with a low degree of processing (oils, grains, leather, meat products, fish, petroleum, wool, fruit, etc.), multinationals ran a deficit of US\$ 4.943 billion in 1997. By contrast, if the same exercise is carried out for locally owned companies, the outcome is still a positive trade balance of US\$ 991 million.

Part of the explanation for the tendency of multinationals (excluding those that export commodities or products with a low degree of processing) to run trade deficits could lie in the difference between their sectoral distribution and that of local companies. Thus, we find that sectors dominated by multinationals, such as the automotive and car parts sector or the telephony services sector, have large trade deficits. In a number of sectors, however, multinational companies run deficits while local ones run surpluses or much smaller deficits, examples being chemicals/petrochemicals, electrical and electronic equipment and machinery, pharmaceuticals, and foods, beverages and tobacco. Again, other than in sectors producing commodities or goods with a low degree of processing, the import ratios of multinationals in all industries are higher than their export ratios. The same is not true of domestic firms, which export more than they import in the food, beverages and tobacco, fuel, electrical equipment and machinery, iron, steel and aluminium and chemicals/ petrochemicals industries. In other words, although the "sector" variable may be important in explaining the differences between the trade balances of the two types of companies, the "origin of capital" variable is significant too, meaning that multinationals may have a tendency to generate negative trade balances irrespective of the business they are in.

Again, taking the 1,000 largest firms by sales, multinationals had higher export ratios on average than local ones in both 1992 and 1997 (table 2). This tendency holds if the most export-oriented sectors are excluded (those working with agricultural or mineral commodities), although when this is done there is a very significant diminution in the export orientation of the leading Argentine companies. If commodity sectors are excluded from the 1997 figures, the average export ratio of subsidiaries of multinationals is just $8.1 \%$, while that of local firms is $4.2 \%$.

It can also be seen that the export orientation of both domestic and multinational firms weakened between 1992 and 1997. This can mainly be put down, however, to a problem with the composition of the sample, as the representation of export-oriented sectors among the largest firms declined. It should also be noted that when these sectors are excluded, average export ratios rose slightly between the years concerned. If nonMercosur export ratios are taken, however, the conclusions from this comparison are reversed.

Where import levels are concerned, the average ratio of multinational firms was more than double that of domestic ones in 1997 (table 2). In a context of freer trade, the tendency towards global sourcing ${ }^{6}$ and the greater ease with which multinationals can supplement the output of their local subsidiaries with products imported from other subsidiaries largely accounts for the propensity of multinationals to import more than their local counterparts.

\footnotetext{
${ }^{6}$ The global sourcing system involves a special relationship between producer and supplier, in which the latter is in a position to supply all of its customer's plants wherever they may be. This may take the form of centralized provision from a factory in a particular country or decentralized provision from plants in the country where the producer is operating.
} 
TABLE 2

Argentina: Trade balance and export and import ratios by sector and origin of capital, 1992 and 1997

\begin{tabular}{|c|c|c|c|c|c|c|c|c|}
\hline \multirow{3}{*}{ Sector } & \multirow{2}{*}{\multicolumn{2}{|c|}{$\begin{array}{c}\text { Trade balance } \\
1997\end{array}$}} & \multicolumn{4}{|c|}{ Export ratio } & \multirow{2}{*}{\multicolumn{2}{|c|}{$\begin{array}{c}\text { Import ratio } \\
1997\end{array}$}} \\
\hline & & & \multicolumn{2}{|c|}{1992} & \multicolumn{2}{|c|}{1997} & & \\
\hline & $\mathrm{LC}^{\mathrm{a}}$ & $\mathrm{MC}^{\mathrm{a}}$ & LC & MC & LC & $\mathrm{MC}$ & $\mathrm{LC}$ & MC \\
\hline Total & 5,042 & 803 & 12.9 & 17.6 & 10.2 & 15 & 8 & 18.8 \\
\hline Total excluding commodities ${ }^{\mathrm{b}}$ & 991 & $-4,943$ & 4.2 & 6.7 & 4.2 & 8.1 & 8.5 & 20.2 \\
\hline Oils and grains & 2,373 & 4,570 & 62.1 & 88.4 & 63.4 & 84.5 & 1.1 & 1 \\
\hline Food, beverages and tobacco & 246 & -18 & 5.6 & 5.9 & 7 & 7.3 & 4.2 & 9.5 \\
\hline Cars and car parts & -9 & -335 & 4.7 & 11.1 & 2.6 & 24.8 & 10.7 & 31.7 \\
\hline Cellulose and paper & -83 & -14 & 6.7 & 4.3 & 5 & 15.1 & 20.6 & 17.2 \\
\hline Fuels and derivatives thereof & 1,574 & -87 & 8.6 & 3.1 & 14.2 & 4.8 & 7.3 & 7.4 \\
\hline Import trade with technical assistance component & -41 & -471 & 0 & 4 & 0.8 & 4.7 & 11.9 & 41.2 \\
\hline Wholesale and retail trade & -527 & -675 & 0.1 & 1 & 1.4 & 0.1 & 8.3 & 32.1 \\
\hline Construction and engineering & -56 & -9 & 0.2 & 0.7 & 0.3 & 0.1 & 2.1 & 2.9 \\
\hline Leather and manufactures thereof & 450 & 194 & 67.8 & 64.5 & 76.5 & 76.2 & 12.2 & 8.3 \\
\hline Publishing/graphics industry & -77 & -35 & 7.4 & 0.4 & 4.7 & 2.9 & 10.2 & 19.7 \\
\hline Electricity, gas and water & 0 & -134 & 0 & - & 0 & 0.8 & 0.1 & 5.1 \\
\hline Household electrical/consumer electronics & -227 & -207 & 0.4 & 0.1 & 2.2 & 10 & 30.5 & 38.3 \\
\hline Pharmaceutical industry & -68 & -518 & 2.3 & 4 & 9.8 & 6 & 12.7 & 33.5 \\
\hline Meat products & 468 & 143 & 37.3 & 53.9 & 26.3 & 44.1 & 4.1 & 1.8 \\
\hline Plastics and rubber products industry & -54 & -170 & 7.8 & 2.3 & 15.8 & 11.2 & 16.4 & 31.1 \\
\hline Electrical and electronic equipment and machinery & 6 & -383 & 6 & 7.3 & 24.3 & 7.5 & 0.7 & 34.6 \\
\hline Engineering and machinery & -89 & -194 & 6.9 & 12.5 & 5.2 & 10.3 & 13.1 & 30.1 \\
\hline Mining & -11 & -3 & 1.2 & 0 & 1 & 63.3 & 6.7 & 58.5 \\
\hline Fisheries & 94 & 137 & 57.8 & 64.7 & 56.9 & 87.7 & 1.2 & 2.9 \\
\hline Petroleum & 417 & 522 & 10.4 & 15.4 & 45.1 & 45.3 & 4.3 & 1.6 \\
\hline Chemicals and petrochemicals & 37 & -757 & 18.5 & 11.8 & 23.7 & 14.6 & 20.3 & 27.2 \\
\hline Telephony services & - & -774 & 0 & 0 & - & 0.1 & - & 24.2 \\
\hline Iron, steel and aluminium & 520 & - & 8.1 & - & 22.5 & - & 12.4 & - \\
\hline Textiles and wearing apparel & 47 & -6 & 3.6 & 14.4 & 5.7 & 17.5 & 11.2 & 32.1 \\
\hline Commodities marketing & 249 & 180 & 57.3 & 81.2 & 47.9 & 81.6 & 5 & 2.9 \\
\hline Transport and storage & -115 & -71 & 0.1 & 0 & 0 & 0 & 5 & 3 \\
\hline Television and multimedia & -8 & -67 & 0 & - & 0 & 0 & 6.8 & 7.4 \\
\hline Glass and non-metallic minerals & -49 & -10 & 5.2 & 6.2 & 6.2 & 9.1 & 9.3 & 10.2 \\
\hline
\end{tabular}

Source: Prepared by the authors on the basis of Argentine external trade statistics and data from Mercado and Prensa Económica magazines.

a $\mathrm{LC}=$ local companies, $\mathrm{MC}=$ multinational companies.

b Excludes oils and grains, leather and manufactures thereof, meat products, fisheries, petroleum and commodities marketing.

To verify more rigorously the hypothesis that the external trade practices of multinationals are different from those of locally owned firms, we proceeded as follows. Pairs of firms were selected from the 1,000 largest companies by sales, one of them locally owned and the other foreign-owned. The companies in each pair belonged to the same sector and differed in size (as measured by sales) by no more than $15 \%$ in 1997 . This made it possible to compare the external trade performance of multinationals with that of an appropriate control group, removing the biases that differences of sector and size can introduce (table 3 ).
What this exercise shows, confirming the findings set forth previously, is that multinational companies export and import more in relation to sales than domestic ones, but that while the latter export more than they import, the opposite is true of multinationals. The exercise described above also allows us to ascertain whether the differences in export/import orientation between multinational and local companies are statistically significant or not. The answer is that they are where import orientation is concerned, but not where export orientation is concerned. In other words, while the statistical evidence supports the theory that

THE STRATEGIES OF MULTINATIONAL COMPANIES IN 1990S ARGENTINA • DANIEL CHUDNOVSKY AND ANDRÉS LÓPEZ 
TABLE 3

Argentina: Comparison of transnational and local companies' trade performance, 1997

(Pairs of companies)

\begin{tabular}{lcc}
\hline & $\begin{array}{c}\text { Exports/ } \\
\text { sales }\end{array}$ & $\begin{array}{c}\text { Imports/ } \\
\text { sales }\end{array}$ \\
\hline No. of pairs & 88 & 115 \\
Average (\%) & 15 & 15 \\
- Multinational companies & 16 & 20 \\
- Local companies & 13 & 10 \\
Standardized difference (\%) & 24 & 58 \\
Z value & 1.59 & 5.24 \\
Statistically significant at 5\% & No & Yes \\
Statistically significant at $1 \%$ & No & Yes \\
\hline
\end{tabular}

Source: Prepared by the authors on the basis of Argentine external trade statistics and data from Mercado and Prensa Económica magazines.

multinationals tend to import more than local firms, the same does not hold true for exports.

Geographically, the external trading pattern of the subsidiaries of multinationals ${ }^{7}$ is quite similar to the external trading pattern of Argentina generally. In 1997, a greater proportion of these companies' exports than of total Argentine exports went to Mercosur, with a smaller proportion therefore going to NAFTA, East Asia and the European Union. As for imports, there was a slight tendency for multinationals to import less from East Asia and NAFTA and to import disproportionately from the "rest of the world" and Europe (table 4, p. 162).

When the export patterns of multinationals and the wider national economy are compared we find, firstly, that multinationals tended to export more commodities (particularly agricultural ones) and less industrial goods, ${ }^{8}$ although the differences from the general

\footnotetext{
7 To process the information on the geographical pattern and composition of multinationals' trade, a sample of the 140 largest multinationals with production operations in the country was put together. This group therefore excluded multinationals that were exclusively importers and those specializing purely in trade and services. The exports of this smaller sample accounted for $22 \%$ and 33\%, respectively, of all Argentine exports in 1992 and 1997, and for $21 \%$ of Argentine imports in 1997. In relation to the entire range of multinationals, this sample accounted for $66 \%$ and $71 \%$ of exports in 1992 and 1997, respectively, and for 36\% of imports in 1997.

${ }^{8}$ The classification employed is useful for depicting the pattern of specialization by multinationals in terms of technology content, factor intensity and the degree of industrialization of the goods marketed by them. This classification was developed by CTP-Data group (Universities of Paris I, XI and XIII) on the basis of Pavitt's traditional classification (1984), which was subsequently adapted by Guerrieri and Milana (1989) and Guerrieri (1992).
}

pattern of the economy are not very significant (table 5, p. 162). Within the industrial goods category, it is found that multinationals exported more natural resourcebased products, agricultural products once again being preponderant.

It might be thought that the classification used, by grouping all agricultural or agro-industrial products in a single category, could be masking the possibility that multinationals might be exporting products that are more sophisticated, either technically or in terms of the market niche they are aimed at, than those of local companies within these groupings. This does not seem to be the case in Argentina, however. There, about 85\% of multinationals' agricultural commodity exports are wheat, maize and soya. These are obviously the type of products that have long been the country's traditional export staples. In the case of agro-industrial manufactures, the bulk of these are flours and oils, which have been one of the country's largest export categories for two decades (over $80 \%$ of multinationals' exports in this category are of these products).

As for manufactures, multinationals export few labour-intensive products, and most of their exports are from industries in which economies of scale are important. Of these, the greatest contribution is made by the automotive industry, which accounts for over $80 \%$ of exports in this group. In 1997, multinationals were less likely than the rest of the economy to export manufactures requiring the use of skills or know-how (specialized suppliers and research and developmentintensive industries). Again, the automotive complex (engines and engine parts) also weighs heavily in the exports of the specialized suppliers group, generating about $70 \%$ of its external sales. When this is considered along with the importance of this complex for exports involving economies of scale, it can be seen that it is essentially through the automotive industry that multinational companies participate in Argentine industrial exports.

What happens when the composition of multinationals' trade flows is analysed by region (table 6, p. 163)? In the case of exports, it transpires that Mercosur is the leading destination for exports of non-natural resource-based industrial products. In fact, Mercosur and LAIA between them take about $90 \%$ of these exports. Exports of commodities and natural resource-intensive manufactures display a different geographical pattern, although Mercosur is important once again as a destination market, particularly in the case of mining- and energy-related products. Countries that do not form part of any regional grouping ("rest of 
TABLE 4

Argentina: Exports and imports by economic area of destination, 1997

(Millions of dollars and percentages)

\begin{tabular}{|c|c|c|c|c|c|c|c|c|}
\hline \multirow[b]{3}{*}{ Economic area } & \multicolumn{4}{|c|}{ Exports } & \multicolumn{4}{|c|}{ Imports } \\
\hline & \multicolumn{2}{|c|}{ Multinationals } & \multicolumn{2}{|c|}{ Argentina } & \multicolumn{2}{|c|}{ Multinationals } & \multicolumn{2}{|c|}{ Argentina } \\
\hline & Value & $\%$ & Value & $\%$ & Value & $\%$ & Value & $\%$ \\
\hline Total & 8,779 & 100.0 & 26,357 & 100.0 & 5,899 & 100.0 & 28,487 & 100.0 \\
\hline LAIA $^{a}$ & 791 & 9.0 & 3,134 & 11.9 & 150 & 2.5 & 1,050 & 3.7 \\
\hline Mercosur ${ }^{b}$ & 3,618 & 41.2 & 9,466 & 35.9 & 1,449 & 24.6 & 7,213 & 25.3 \\
\hline NAFTA $^{\mathrm{c}}$ & 342 & 3.9 & 2,445 & 9.3 & 1,268 & 21.5 & 6,634 & 23.3 \\
\hline Rest of world & 2,148 & 24.5 & 4,643 & 17.6 & 798 & 13.5 & 2,203 & 7.7 \\
\hline East Asia ${ }^{\mathrm{d}}$ & 727 & 8.3 & 2,730 & 10.4 & 350 & 5.9 & 3,558 & 12.5 \\
\hline European Union ${ }^{\mathrm{e}}$ & 1,153 & 13.1 & 3,939 & 14.9 & 1,883 & 31.9 & 7,828 & 27.5 \\
\hline
\end{tabular}

Source: Prepared by the authors on the basis of external trade statistics.

${ }^{a}$ Latin American Integration Association (excluding Mexico and Mercosur).

b Southern Common Market.

c North American Free Trade Agreement.

d Includes China, Hong Kong, Indonesia, Japan, Malaysia, the Philippines, the Republic of Korea, Singapore, Taiwan Province of China and Thailand.

e European Union.

TABLE 5

Argentina: Exports by product type, 1997

(Millions of dollars and percentages)

\begin{tabular}{|c|c|c|c|c|c|}
\hline \multirow[b]{3}{*}{ Sector } & & \multicolumn{4}{|c|}{ Exports } \\
\hline & & \multicolumn{2}{|c|}{ Multinationals } & \multicolumn{2}{|c|}{ Argentina } \\
\hline & & Total & $\%$ & Total & $\%$ \\
\hline \multicolumn{2}{|l|}{ Total } & 8,779 & 100.0 & 26,357 & 100.0 \\
\hline \multicolumn{2}{|l|}{ Subtotal } & 8,754 & 99.7 & 26,317 & 99.8 \\
\hline \multicolumn{2}{|c|}{ 1. Commodities } & 2,842 & 32.4 & 8,335 & 31.6 \\
\hline \multicolumn{2}{|c|}{ 1.10 Agricultural } & 2,433 & 27.7 & 5,916 & 22.4 \\
\hline \multicolumn{2}{|c|}{1.20 Mining } & 0 & 0.0 & 114 & 0.4 \\
\hline \multicolumn{2}{|c|}{1.30 Energy } & 409 & 4.7 & 2,305 & 8.7 \\
\hline \multicolumn{2}{|c|}{ 2. Industrial products } & 5,912 & 67.3 & 17,982 & 6.2 \\
\hline \multirow{5}{*}{2.1} & Natural resource-intensive industries & 3,353 & 38.2 & 9,619 & 36.5 \\
\hline & 2.11 Labour-intensive agricultural industries & 2,831 & 32.2 & 6,913 & 26.2 \\
\hline & 2.12 Other agricultural resource-intensive industries & 119 & 1.4 & 860 & 3.3 \\
\hline & 2.13 Mining & 144 & 1.6 & 832 & 3.2 \\
\hline & 2.14 Energy & 259 & 2.9 & 1,006 & 3.8 \\
\hline \multicolumn{2}{|c|}{ 2.2 Manufactures } & 2,559 & 29.2 & 8,362 & 31.7 \\
\hline & 2.22 Labour-intensive industries & 92 & 1.1 & 2,048 & 7.8 \\
\hline & 2.23 Industries that exploit economies of scale & 1,838 & 20.9 & 4,303 & 16.3 \\
\hline & 2.24 Specialized suppliers & 370 & 4.2 & 1,133 & 4.3 \\
\hline & 2.25 R\&D-intensive industries & 259 & 2.9 & 881 & 3.3 \\
\hline
\end{tabular}

Source: Prepared by the authors on the basis of external trade statistics and Porta and Anllo (1998).

THE STRATEgIES OF MULTINATIONAL COMPANIES IN 1990S ARGENTINA - DANIEL CHUDNOVSKY AND ANDRÉS LÓPEZ 
TABLE 6

Argentina: Geographical distribution of external trade conducted by the subsidiaries of multinational companies, by product type, 1997

(Percentages)

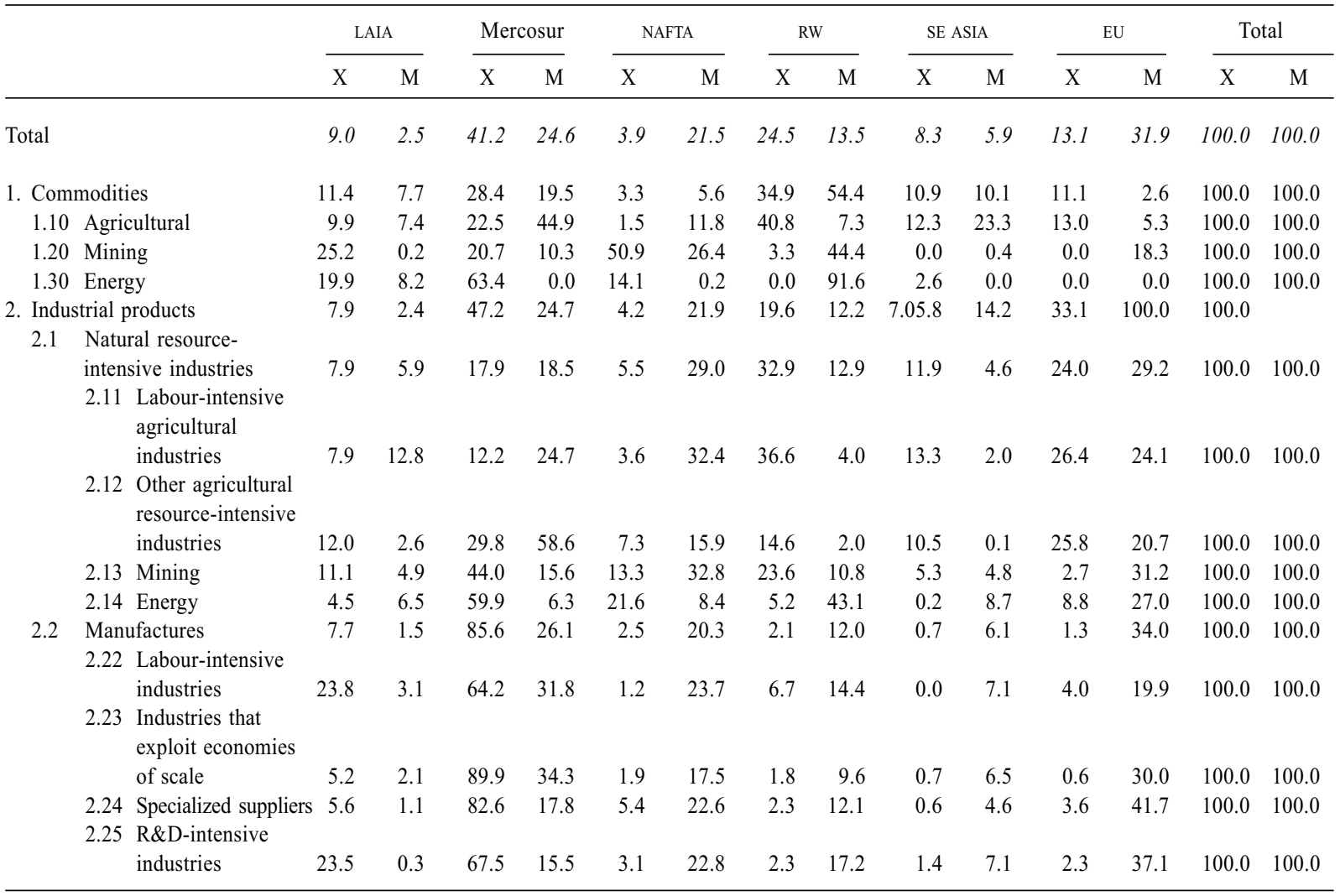

Source: Prepared by the authors on the basis of external trade statistics.

the world"), and to a lesser extent the European Union and South-East Asia, are the main recipients of agriculture-related goods, while NAFTA is a significant purchaser of mining/energy products exported by the subsidiaries of multinational companies in Argentina. In other words, multinationals export their most sophisticated products (in terms of technology and production techniques) to the Latin American countries, particularly Mercosur, while what they sell to the developed countries are mainly commodities or natural resource-intensive manufactures.

What about imports? The pattern clearly has the opposite tendency to the one described for exports. Mercosur is important as a source of imports for the subsidiaries of multinationals in almost all industries, but particularly in the case of commodities and agriculture-linked manufactures. By contrast, manufacturing imports, and especially those included in the specialized suppliers and R\&D-intensive categories, tend to come mainly from the European Union and the NAFTA countries.

Lastly, it is interesting to analyse the extent to which the external trade of multinationals is conducted with the home countries of their respective parent companies. In the case of exports, these home countries are of very little importance as destination markets. In 1997, only Brazilian and Chilean companies showed some tendency to export disproportionately to their respective home countries. In all other cases, the percentage of exports sent by subsidiaries to the countries in which their parent companies were located was generally between zero and $3 \%$. The situation is no different if the regional blocs to which the home countries of parent companies belong are considered. Thus, neither NAFTA nor the European Union were export destinations of any particular importance for Canadian or United States companies, in the former case, or European ones, in the latter.

THE STRATEGIES OF MULTINATIONAL COMPANIES IN 1990S ARGENTINA • DANIEL CHUDNOVSKY AND ANDRÉS LÓPEZ 
The picture changes when the imports of companies in the sample are analysed. The proportion of imports coming from the home countries of subsidiaries' parent companies in 1997 was $61 \%$ for Brazil, $60 \%$ for France, $54 \%$ for Japan, $42 \%$ for Switzerland, $36 \%$ for Germany, $32 \%$ for Great Britain and almost $30 \%$ for the United States and Canada. Again, NAFTA was the source for $80 \%$ of Canadian companies' imports, and the European Union for $91 \%$ of Belgian companies', for example. By contrast with the situation for exports, in other words, there is quite a clear association in many cases between the origin of multinationals and the origin of their imports.

\section{IV}

\section{General conclusions and policy}

\section{suggestions}

Let us return to the questions asked in the introduction to this article. Do the strategies and objectives of multinational companies in an open economy differ from those seen during the ISI phase? Yes, but not as much as might be imagined, considering how the ground rules changed in the 1990s.

The basic objective of subsidiaries of multinationals in Argentina is still to exploit the domestic market. It is clear, however, that there are two substantial differences from the ISI phase: access to the Brazilian market under Mercosur has made greater economies of scale and specialization possible, and increased competition in many tradable sectors is forcing subsidiaries to bring their production operations more into line with international best practice.

These differences are not reflected, however, in the trading patterns of subsidiaries, which the findings of this study suggest are not much different from what they were under ISI.

Manufacturing exports, which are only a small proportion of total sales, go mainly to Mercosur; exports to the developed countries consist essentially of commodities and natural resource-based manufactures with a low degree of processing. Manufacturing imports, and particularly more technologically complex ones, come mainly from the developed countries, largely from the home country or region of the subsidiary's parent company.

Other than in a few industries that exploit economies of scale (essentially the automotive sector, where the prevailing regime has encouraged the regionalization of Argentine subsidiaries), multinationals' exports are essentially based on the use of resources. There are almost no exports of R\&D-based goods or products from specialized suppliers. Thus, rather than being agents of change in the pattern of export specialization, multinationals have generally helped entrench the traditional composition.

Although the subsidiaries of multinationals have substantially higher import ratios than local firms, which ought to give them cost and quality advantages (where purchases of inputs and capital goods are concerned) or advantages of scale and scope (when finished products are imported), the differences in their respective export ratios are not statistically significant when sector and size are adjusted for. In fact, multinationals' exports outside Mercosur as a proportion of total sales fell between 1992 and 1997: in the latter year, only a little over $4 \%$ of multinationals' sales were exports of this kind, while their export ratio barely exceeded $8 \% .{ }^{9}$ This would suggest that multinationals have not helped increase the access of Argentine products to outside markets, considering that Mercosur became a "natural" market for Argentine exports in the 1990s.

It could be argued that FDI helped to increase Argentine exports indirectly, e.g., through investment in communications, energy and transport infrastructure, but this effect does not seem to have been very substantial in the 1990s. In fact, although exports grew strongly during that decade, largely because of

\footnotetext{
${ }^{9}$ Another interesting fact is that, according to estimates by the Bureau of Economic Analysis of the United States Department of Commerce, if the exports of subsidiaries of United States multinationals in Argentina in 1983 and 1998 are compared, no increase whatsoever is seen in the average ratio of exports to sales between the two years.
}

THE STRATEGIES OF MULTINATIONAL COMPANIES IN 1990s ARGENTINA • DANIEL CHUDNOVSKY AND ANDRÉS LÓPEZ 
increased external sales by sectors with natural comparative advantages (cereals, oilseeds, oils and petroleum, and activities strongly supported by the public sector, such as car manufacturing), ${ }^{10}$ exports did not rise significantly as a proportion of GDP, and this proportion is still low by international standards (the export/GDP ratio rose from $7.8 \%$ in $1991-1995$ to $10.4 \%$ in 1996-1999).

While stand-alone operations are still usual among the subsidiaries of multinationals, there has been a shift towards integration strategies. These, however, are generally of the "simple" type, and in most cases links with the company are weak. Only in the automotive complex has there been more vigorous integration of subsidiaries (basically within Mercosur) owing both to public policies and to the global strategies of multinationals, although invariably, as in other sectors, local subsidiaries have little independence and innovation and strategic activities are almost never decentralized.

Thus, there is as yet no sign in Argentina of the tendencies that, according to the literature examined, should be leading multinationals to implement new, more active strategies to integrate their subsidiaries into intracompany trade, production and technology networks. In particular, innovation and strategic management activities are not being decentralized, and there is no move towards the sort of "world product mandates" that would give subsidiaries exclusive responsibility for worldwide sales of a particular product, measures that entail a high degree of independence for subsidiaries and that yield major externalities for the recipient economy.

Taken all together, in short, the data examined in the study suggest that the private gains accruing to the "winners" among the country's top companies from improved microeconomic performance have not yet had any major spillover effects in the Argentine economy. This is amply illustrated by the low export ratios of the subsidiaries of multinationals and by the limited diversification of their destination markets and the low degree of linkage seen hitherto between exports and clearly defined intracompany specialization and integration strategies. Although they have not been specifically examined in this paper, the spillover effects generated by multinationals up and down the country's

\footnotetext{
${ }^{10}$ About $75 \%$ of the increase in Argentine exports between 1990 and 1998 was due to higher sales of cereals, oilseeds, oils, leather, fish products, fruit and vegetables, petroleum and cars.
}

production chains seem to be weak as well, as do the effects on local technology efforts and the transfer of efficiency gains to consumers in areas where the discipline of trade liberalization is not enough to promote competition.

Has FDI, then, helped the restructuring of the Argentine economy to achieve the results expected by its advocates? Clearly, more issues than have been covered here would need to be analysed for this question to be answered. To confine ourselves to what has been dealt with in this article, however, we can say that its contribution has at any rate been less than might have been expected, considering both the new situation in Argentina and the differences between the way FDI works now and the way it worked during the ISI phase.

What policy conclusions does this analysis yield? The fact that many of the world's leading multinationals have operations in Argentina is certainly a useful asset which, in our opinion, has not yet been sufficiently capitalized upon to improve the country's competitiveness in a globalized economy. We do not believe, therefore, that the only possible line of policy is the one followed hitherto, i.e., increasing the general attractiveness of the country for investors and trusting that the performance of multinationals will produce greater spillover effects as time passes and stability and growth in the economy are secured.

This stance, the dominant one in Argentina, is challenged by another current of thinking that attributes to FDI (or, more vaguely, to globalization) a variety of social costs, such as rising unemployment or the bankruptcy of many local firms. According to this view, the costs of FDI clearly exceed its benefits. Certainly, the rationalization measures adopted by multinationals have generally resulted in labour being shed, and their rise has meant the closure of many local firms that were unable to compete with them, or could not meet the conditions of price, quality, etc., that they demanded of their suppliers. In our opinion, though, these effects can mainly be put down to the particular way in which the switch to the new economic regulation model was made in the 1990s. To offset costs of this type, it is better to adopt policies that complement trade liberalization, something that has long been put off in Argentina, than to reject the participation of multinationals in the country's economy.

We believe, and international experience suggests, that the potential contribution of FDI will only be realized fully once a more "proactive" 
strategy has been adopted. A more aggressive export promotion and market diversification policy, ${ }^{11}$ measures to attract investment projects with export potential and initiatives by multinationals that boost the development of local suppliers ought to be some of the components of this "proactive" strategy, which would have to be compatible with World Trade Organization (WTO) rules and be designed with a view to ensuring that trade and industrial policy instruments do not consolidate situations of inefficiency within the local production system, as they did in the past.
In summary, there is a broad positive agenda for policy towards multinationals. This agenda is more active than the one followed by the national Government in the 1990s but, unlike the one put forward by "anti-globalization" movements, what it proposes are not restrictions on the operations of multinationals but measures to increase the benefits and reduce the costs deriving from them. If this is done, the privilege of belonging to the small club of developing countries that attract large quantities of FDI will translate far more clearly than it has so far into tangible benefits for economic development in Argentina.

\section{Bibliography}

Bonvecchi, C. (1995): "Las filiales argentinas de las empresas transnacionales de EE.UU. Rasgos centrales y desempeño reciente", Working document, No. 62, Buenos Aires, ECLAC office in Buenos Aires.

Chudnovsky, D. and A. López (1998): "La inversión extranjera directa en la Argentina en los años 1990: tendencias, determinantes y modalidades", in Ministry of Foreign Affairs, Worship and International Trade, La Argentina de cara al mundo. Hacia una nueva inserción en la economía internacional. Aportes para un debate necesario, Buenos Aires.

(2001): La transnacionalización de la economía argentina en los años 1990, Buenos Aires, EUDEBA.

Chudnovsky, D., F. Porta and others (1996): Los limites de la apertura, Buenos Aires, Research Centre for Industrial Transformation (CENIT)/Alianza Editorial.

Dunning, J.H. (1988): Explaining International Production, London, Unwin Hyman.

(1996): Re-evaluating the benefits of foreign direct investment, in United Nations Conference on Trade and Development (UNCTAD), Companies without Borders: Transnational Corporations in the 1990s, London.

Guerrieri, P. (1992): Technology and trade performance of the most advanced countries, unpublished.

Guerrieri, P. and C. Milana (1989): L'industria italiana nel commercio mondiale, Bologna, Italy, Ed. Il Mulino.

Kosacoff, B. (ed.) (1998): Estrategias empresariales en tiempos de cambio, Buenos Aires, Economic Commission for Latin America and the Caribbean (ECLAC)/Quilmes National University.

${ }^{11}$ The objective of increasing exports should certainly be one of the central pillars of any economic development strategy in Argentina, and this means working in different areas to lower costs, improve market access, boost microeconomic competitiveness, etc. In the case of multinationals, however, there are some specific factors that suggest there is scope for raising export levels significantly by means of negotiations whereby the country can capitalize more fully on the potential access that multinationals have to developed country markets by virtue of the global nature of their operations.
Kosacoff, B. and D. Aspiazu (1989): La industria argentina: desarrollo y cambios estructurales, Buenos Aires, Centro Editor de América Latina/ECLAC office in Buenos Aires.

Kosacoff, B. and G. Bezchinsky (1993): "De la sustitución de importaciones a la globalización. Las empresas transnacionales en la industria argentina", in B. Kosacoff and others (eds.), El desafio de la competitividad. La industria argentina en transformación, Buenos Aires, Alianza Editorial.

Kosacoff, B. and F. Porta (1997): "La inversión extranjera directa en la industria manufacturera argentina", Estudios de la economía real, No. 3, Buenos Aires, ECLAC office in Buenos Aires.

Pavitt, K. (1984): Sectoral patterns of technical change: towards a taxonomy and a theory, Research Policy, No.13, Amsterdam, Netherlands, North Holland.

Porta, F. and G. Anllo (1998): “Contenidos tecnológicos del comercio exterior argentino. Un análisis descriptivo del periodo 1986-96", Buenos Aires, Quilmes National University, unpublished.

Porta, F. (1999): "O investimento direto estrangeiro na Argentina nos anos 90: fatores de atração e estratégias empresariais", in D. Chudnovsky (org.), Investimentos externos no Mercosul, São Paulo, State University at Campinas (UNICAMP)/Papirus.

Sourrouille, J., F. Gatto and B. Kosacoff (1984): Inversiones extranjeras en América Latina. Política económica, decisiones de inversión y comportamiento económico de las filiales, Buenos Aires, Institute for the Integration of Latin America and the Caribbean (INTAL)/Inter-American Development Bank (IDB).

Sourrouille, J., J. Lucangeli and B. Kosacoff (1985): "Transnacionalización y política económica en Argentina", Buenos Aires, Centro de Economía Transnacional/Centro Editor de América Latina.

UNCTAD (1994): World Investment Report 1994. Transnational Corporations, Employment and the Workplace, Geneva.

World Bank (1991): World Development Report 1991, Washington, D.C.

(2000): World Development Report 1999/2000, Washington, D.C. 